\title{
DEMOGRAPHIC CHANGES IN CARPATHIAN MOUNTAIN SPACE. CASE STUDY: CITIES FROM SOUTHERN CARPATHIANS (ROMANIA)
}

\author{
Mădălin-Sebastian Lung ${ }^{A}$ \\ Received: February 19, 2019 | Accepted: April 4, 2019 \\ DOI: 10.5937/ZbDght1901001L
}

\begin{abstract}
The aim of the study is to analyze the demographic changes in the cities of the Southern Carpathians. The period studied is 1993-2017. The demographic indicators by which we analyzed the demographic dynamics were: birth, mortality and natural growth. For the first two we also focused on the evolution of the number of newborns and deceased. The necessary data were obtained from the National Institute of Statistics. Their processing was done with the ARC Gis 10.3, and maps were made with the distribution of rates for each indicator. In addition to the maps, graphs of the numerical evolution of newborns and deceased have been made. The decreases in demographic values have been assimilatedwith the negative processes of the mining industry. Basically, cities in the Petroşani Coal Basin faced visible decreases of newborns, a cause being the gradual loss of industrial function. Job losses have led to the installation of insecurity of income insurance, which has been passed on to the organization of families. The entire urban area of the Southern Carpathians faces demographic dysfunctions generated by demographic changes. The natural growth in the period 1993-2017 showed that depopulation is a risk phenomenon that is being carried out in the urban environment of the Southern Carpathians.
\end{abstract}

Keywords: demographic changes, Carpathian Mountain Space, cities, Romania, ARC Gis.

\section{INTRODUCTION}

The study of population dynamics is an intense subject to research at global level. The demographic component is constantly moving in an increasingly globalised world. Demographic research in Romania targeted many geographic regions, realizing true studies of population geography and settlements (Niţă, 2007; Raţiu, 2007; Tănasă, 2007; Ionescu, 2009; Mihalca, 2010; Constantin, 2011; Misachevici, 2011; Vîlcea, 2011; Fonogea et al., 2012; Tofan, 2012; Surd et al., 2017; Lung, 2018; Lung, Gligor, 2018). A short time

A Babeș-Bolyai University, Doctoral School of Geography, Cluj-Napoca, Romania; contact: lungmadalin@yahoo.com 
ago a study was conducted on demographic dynamics in the rural area of the Southern Carpathians (Persu, 2017).The dynamic component is the research topic for many researchers around the world. There has been a great diversity of studies on natural dynamics, the migrants concerned have tried to find reasons for the variety of situations that induce risk of demographics (Josipovic, Repolusk, 2003; Attané, Barbieri, 2009; Prioux, Mazuy, 2009; Babović et al., 2016; Kokotović et al., 2016; Marinković, Radivojević, 2016; Jani, 2018).

The aim of the study is to analyse the demographic changes of the urban area of the Southern Carpathians. Through this study we wanted to see how the population evolved through mortality, birth and natural growth during the post-socialist period. We also wanted to see how the population of the Petroşani Coal Basin (or Petroşani Depression) was presented after the socialist period. During socialism, the main function was the industrial mining, which helped to the prosperity of the demographic component. Starting with 1989, industrial function began to pieradă of importance, reaching massive redundancies and closures of mining activities. After that, socio-demographic risks have arisen that have been passed on to the evolution and demographic dynamics.

Unfortunately, the population in the urban area of the Southern Carpathians has declined since 1993 compared with the year 2017. Demographic changes in cities were based on socio-economic factors following restructuring in the industrial sector started immediately after the fall of socialism. These socio-economic factors have had repercussions on demography, influencing the start of significant demographic changes. The instability of the living standards and the uncertainty of an economic income, imposed the numerical decrease of demographics indicators such as the number of newborns, respectively the decrease in birth rates. In parallel, the numerical values of deaths and mortality rates increased. Following demographic changes, it was found that the natural increase rates had negative values for most cities, with only two exceptions. As a consequence, urban space in the Southern Carpathians is faced with demographic phenomena such as depopulation, where major demographic failures may occur.

\section{METHODOLOGY}

The first stage consisted in the delimitation of the geomorphologic of the Southern Carpathians. The geomorphologic map was used to obtain this limit (Posea, Badea, 1984). After the physical limit has been established, the administrative limit has been outlined. The identification of the administrative-territorial units belonging to the space of the Southern Carpathians was made according to criteria used by other researchers in their works. The administrative delimitation was carried out after consulting the geographical specialized bibliography (Persu, 2017; Surd et al., 2017). Following the acquisition of the administrative limit, the cities were identified. Thus, the urban area of the Southern Carpathians is made up of 31 cities, distributed on the territory of nine counties': Băile Herculane (Caraș-Severin County), Simeria, Orăștie, Hunedoara,

1 Administrative-territorial unit, in Romania, in which several towns and municipalities enter. 
Călan, Deva, Hațeg, Petrila, Aninoasa, Petroșani, Vulcan, Lupeni, Uricani (Hunedoara County), Cugir, Sebeș (Alba County), Tălmaciu, Săliște, Cisnădie, Avrig (Sibiu County), Zărnești (Brașov County), Bușteni, Sinaia, Comarnic (Prahova County), Brezoi, Călimănești, Băile Olănești, Horezu (Vâlcea County), Novaci, Bumbești-Jiu, Tismana (Gorj County ), Baia de Aramă (Mehedinți County). (Figure 1)

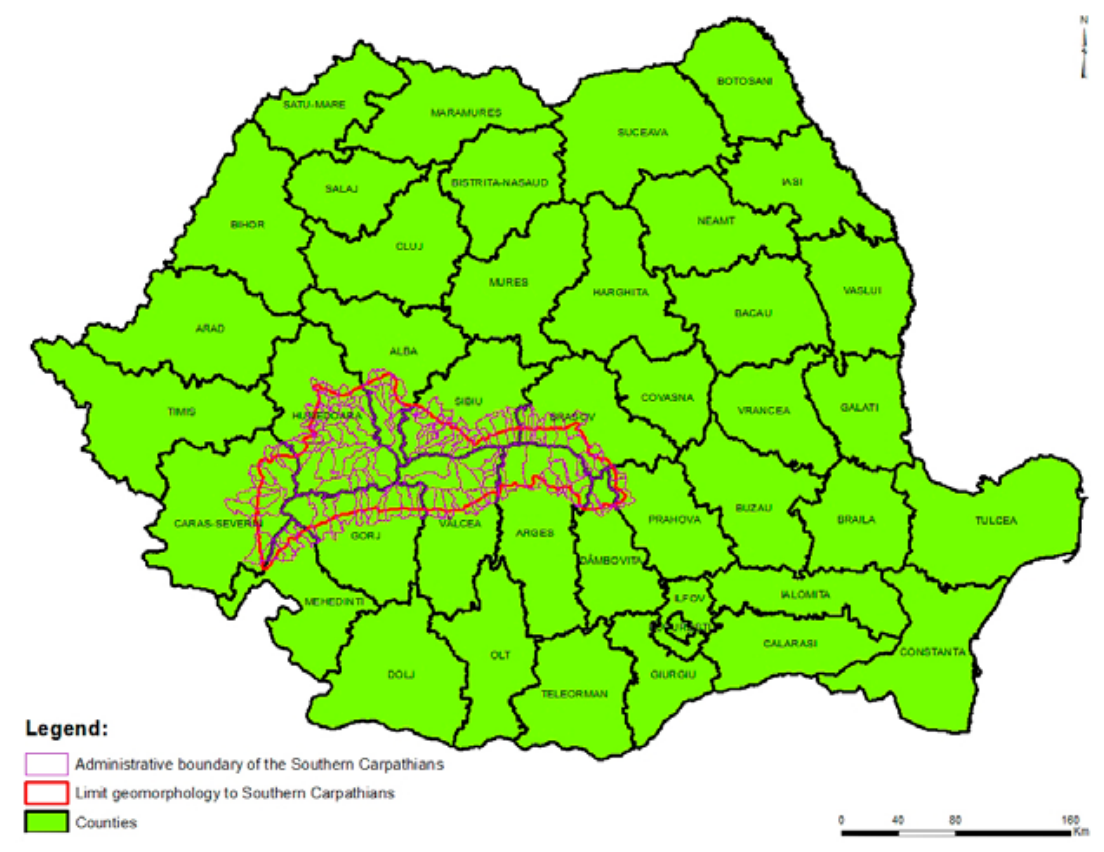

Figure 1. Geographical position of the Southern Carpathians Source: own study

The next stage after the identification of cities, was the acquisition of statistical data required for the study (number of newborns, number of deaths, then calculating thebirth rates, mortality rates, natural growth rates). The data for the year 1993 and 2017 on demographic changes were obtained from the National Institute of Statistics. The data was processed with Microsoft Excel 2013, and the resulting database was entered in the attribute table of the ARC Gis 10.3 program. Several series of graphs and maps have been generated for each of the analyzed indicators. We have also tried to find some causes that led to the increase or decrease in the values of some indicators in those cities where prosperity during the socialist period was due to industrial function, which after 1989 began to lose its importance. Thus, all of the National Institute of Statistics we obtained data needed to achieve a work force painting that activated in the mining industry. After processing data on the herd of labor mass, we were able to formulate some opinions in which we corroborated the negative processesin the mining industry with the negative evolution of demographic indicators. 


\section{RESULTS AND DISCUSSIONS}

In the urban area of the Southern Carpathians were identified 31 cities, which belong to nine counties ${ }^{2}$. Demographic evolution is presented in Figure 2. They had in the year 1993, a population of 638468 inhabitants. Of these, 12 had under 10000 inhabitants in the year 1993, 9 had between 10000 and 20000 inhabitants, 3 had between 20000 and 30000 inhabitants, 4 had between 30000 and 40000 inhabitants, and 3 passed by 40000 inhabitants. The largest demographic city in the Southern Carpathians was the town of Hunedoara which in 1993 had a population of 86314 inhabitants. Also from the same county were the following two cities, Deva, which had 78887 inhabitants, respectively the city of Petroşani which had 51116 inhabitants. We see that the largest 3 cities in the studied region are from Hunedoara County. Cities that have had under 10000 inhabitants are dispersed in the territory of several counties. Thus, in the year 1993 the city with the smallest population was the Băile Olănești, which registered 4845 inhabitants. The other cities that had less than 10000 inhabitants are: Aninoasa 5019, Baia de Aramă 5824, Băile Herculane 6092, Săliște 6144, Novaci 6629, Brezoi 7165, Horezu 7602, Tismana 8401, Călimănești 8871, Tălmaciu 9207, Bumbești-Jiu 9936. We see that the smallest administrative units in demographic size extend to the territory of 6 counties.

After 24 years, the number of administrative units with less than 10000 inhabitants increased to 14. In the year 2017 compared to 1993, their flock increased by 2 cities. The two units to be added to the 12 of 1993 are: Uricani and Bușteni. The maximum and minimum demographic values are maintained as in 1993, but with demographic decreases for 27 of the cities. In 2017, the total population of the 31 cities was 569100 inhabitants. It can be found a demographic decrease of 69368 inhabitants, meaning a percentage decrease of $10.8 \%$ in the 24 years. Hunedoara lost the largest number of inhabitants. From 1993 to 2017, the population of the city fell by 12973 people, losing $15 \%$ of the population. The second largest decrease was in Deva where the population fell by 9200 people, a percentage decrease of $11.6 \%$. In third place, the highest decrease was Petroşani, dropping by $17 \%, 8690$ inhabitants. These three cities had the largest number of population in both 1993 and 2017. The decreases are justified due to the fact that they had the highest population number. In 1993, the three units together 216317 inhabitants (33.8\% of the total urban population of the Southern Carpathians), and in 2017 had 185464 inhabitants (32.5\% of the total urban population in the Southern Carpathians), registering a demographic loss number of 30853 persons and a percentage loss of $14.2 \%$. The mining towns of the Petroşani Depression have lost large herds of population. Lupeni lost in 24 years, no less than 7138 inhabitants, meaning a population decrease of $21.1 \%$. Vulcan recorded a decrease of $18.1 \%$, losing 6318 inhabitants in the analyzed time interval. Petrilawas depopulated with 4774 people, with a decrease of $16.2 \%$. Uricani was depopulated by $18.4 \%$, meaning a decrease of 2188 people.

At the opposite pole with the lowest demographic decreases were all 3 cities, which lost each under 100 inhabitants. With the smallest decrease in the population was the Brezoi, which lost only 34 people. The following two were: Călimăneşti with 53 people

2 Administrative-territorial unit, in Romania, in which several towns and municipalities enter. 
and Bumbeşti-Jiu with 73 people. The numerical decrease of the three was only 160 people. To note, there are four administrative units that have had demographic growth between 1993-2017. These are: Cisnădie, Sebeș, Avrig and Zărnești. The city of Cisnădie had the largest numerical increase of 3019 inhabitants. The percentage increase was $10.3 \%$. The second largest numerical increase of 1624 people was in Sebeş, meaning an increase of 5.2\%. The population of Avrig grew by 1465 inhabitants (10.3\%) and the town of Zărnești increased by 51 people $(0.1 \%)$. The demographic contribution of the four cities was 6159 people.

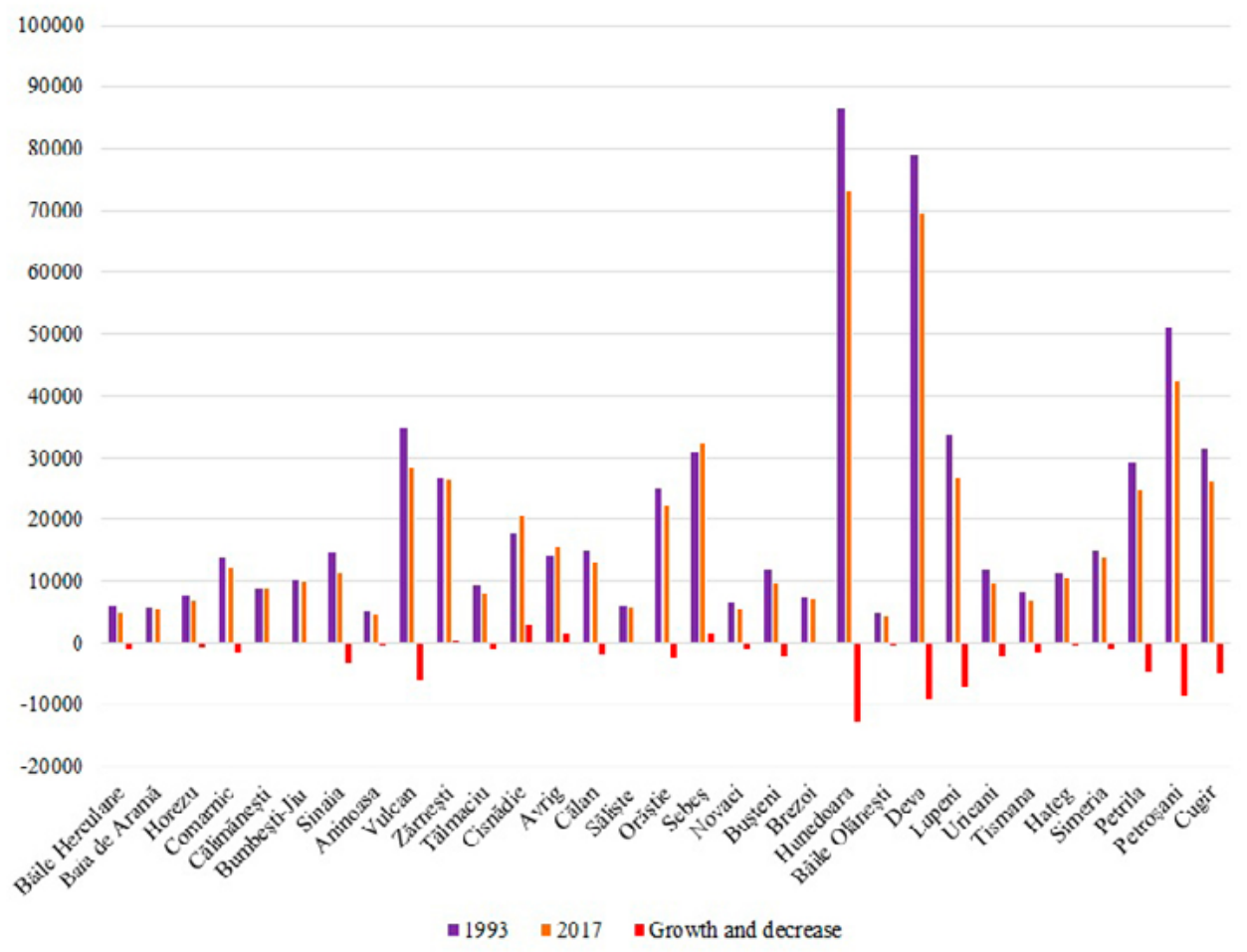

Figure 2. Population change in the urban area of the Southern Carpathians in 1993 and 2017 Source: own study based on data from National Institute of Statistics

The birthplace of the urban environment of the Southern Carpathians in 1993 and 2017 was in a continuous decrease. The dynamics of the flocks of newborns is presented in Figure 3. In the year 1993, the 31 administrative units registered 7254 newborns. The maxim was in Hunedoara where there were 956 newborns (11\%), followed by Petroşani with $684(13.3 \%$ ) and Deva with $644(8.1 \% 0)$. These three cities had together 2284 newborns, representing $31.4 \%$ of the whole flock of newborns. 11 cities had under 100 newborns in 1993 (Tălmaciu 10.5\%o, Brezoi 12.8\%o, Bumbești-Jiu 9.2\%o, Horezu 12.1\%o, Sinaia 6.3\%o, Bușteni 7.2\%o, Băile Olănești 14.8\%o, Novaci 10.5\%o, Săliște 11.3\%o, Aninoasa $13.5 \%$, Băile Herculane $9.8 \%$ ). The number of newborns in the 11 was 891 , representing $12.2 \%$ of the total number. 
In 2017, the number of newborns decreased to 4330, with a decrease of $2924(40 \%)$ of births compared to 1993. All cities had decrease of the number of newborns, except for Cisnădie where the flock of newborns was 195 in 1993 and 2017. The first three highest values also had significant decreases in the herds. In Hunedoara the number of newborns was 533, in decrease by $44.2 \%$, compared with 1993. Deva had 500 births, decreasing by $22.3 \%$, and Sebeșul was ranked third with 313 newborns. Decrease Sebeșului was 14.9\%. The three mentioned administrative units had the highest number of newborns in 2017.

There are several situations in the case of mining towns where the number of births has fallen far from 1993. Petrila had a 55.1\% decrease in births. The town of Petroşani had a difference in 1993-2017 of 390, a 57\% decrease. Vulcan recorded a loss of 315, which means a decrease of $58 \%$. In Lupeni, the most profound decrease of newborns was recorded, which was $59.2 \%$. The four cities were heavily industrialised in the socialist period, and the Revolution of 1989 had acute consequences on the evolution of these cities. Industrial function gradually disappeared until 2000, on the evolution of demographic indicators.

The distribution of birth rates in the urban area of the Southern Carpathians in 1993 is presented in Figure 4. The birth rate of 1993, surprised eight cities that had the rate

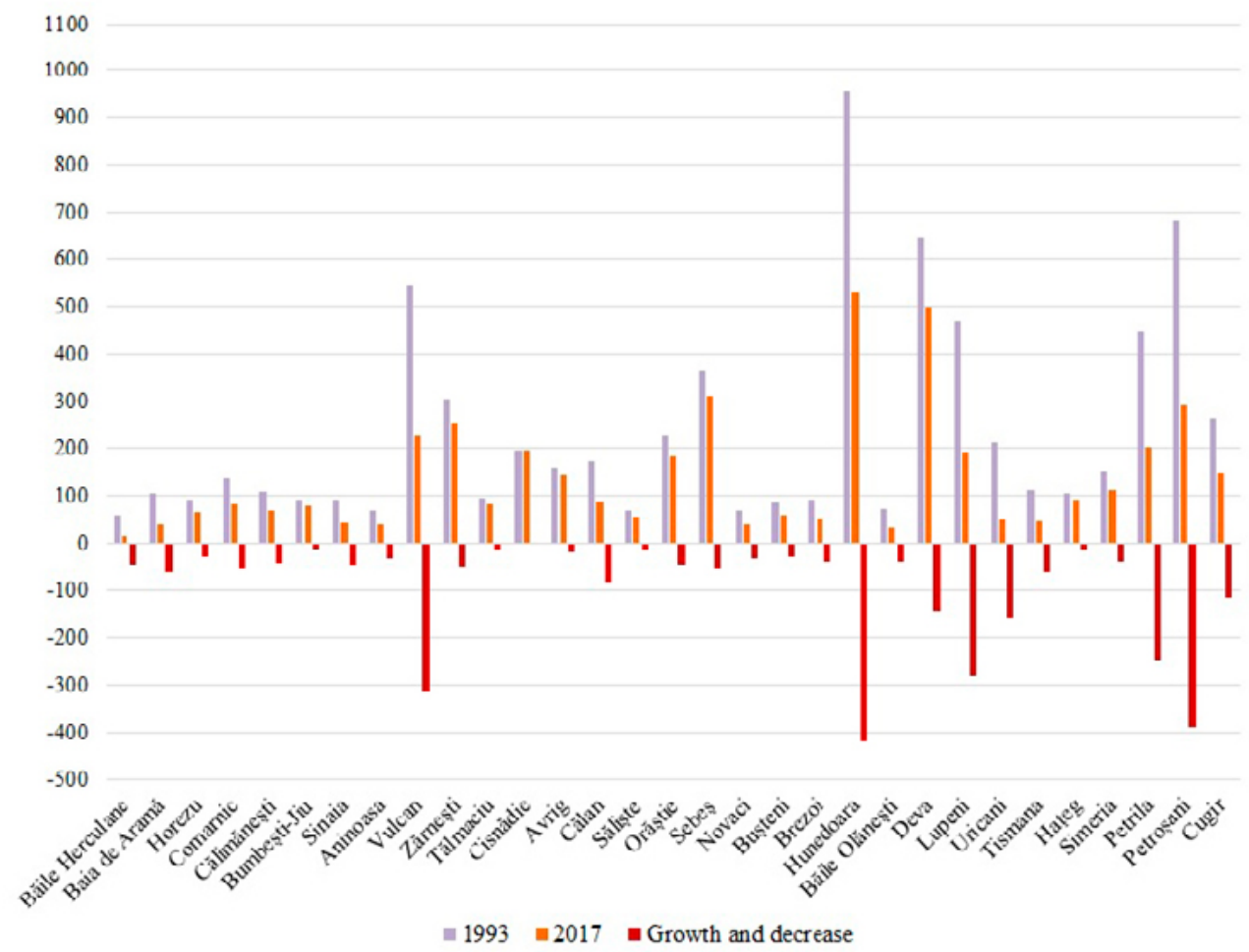

Figure 3. The numerical evolution of newborns in the urban area of the Southern Carpathians in 1993 and 2017

Source: own study based on data from National Institute of Statistics 
below $10 \%$. The lowest rate was recorded in the city of Sinaia, $6.3 \%$. The following seven instalments were: Bușteni $(7.2 \%)$, Deva $(8.2 \%)$, Cugir $(8.3 \%)$, Hațeg $(9.2 \%)$, Orăștie $(9.2 \%)$ ), Bumbești-Jiu $(9.3 \%)$, Băile Herculane $(9.8 \%$ ). Most birth rates were included in the 10.1-15\%. 19 administrative units had the rates between those values. From 31 cities, only four had rates higher than $15.1 \%$. Note that three cities are from the Coal Basin Petroşani (Petrila 15.2\%o, Vulcan 15.6\%o, Uricani 17.8\%). The industrial function of the three cities has passed on the evolution of the birth of 1993. The large workforce was trained in the mining industry, so the dynamic component could thrive. According to the data provided by the National Institute of Statistics, in the year 1992, the majority of the workforce in the three administrative units worked in the mining and processing industries. The active population of the trills amounted to 11858 people, of which 6838 (57.6\%) were trained in mining and $1713(14.4 \%)$ in the manufacturing industry. In Uricani the active population was 5218, of which 3529 (67.6\%) were working in mining extraction, and $320(6.1 \%)$ in the processing industry. At the Vulcan the active population amounted to 15012, and in the mining industry were 7616 (50.7\%) and in the processing were 2632 (17.5\%). Basically, the two industrial branches held the highest workforce: in Petrila $72 \%$ of the active population worked in extraction and processing, Vulcan $68.2 \%$, and in Uricani $73.7 \%$. From this data we can see that the industrial function clearly

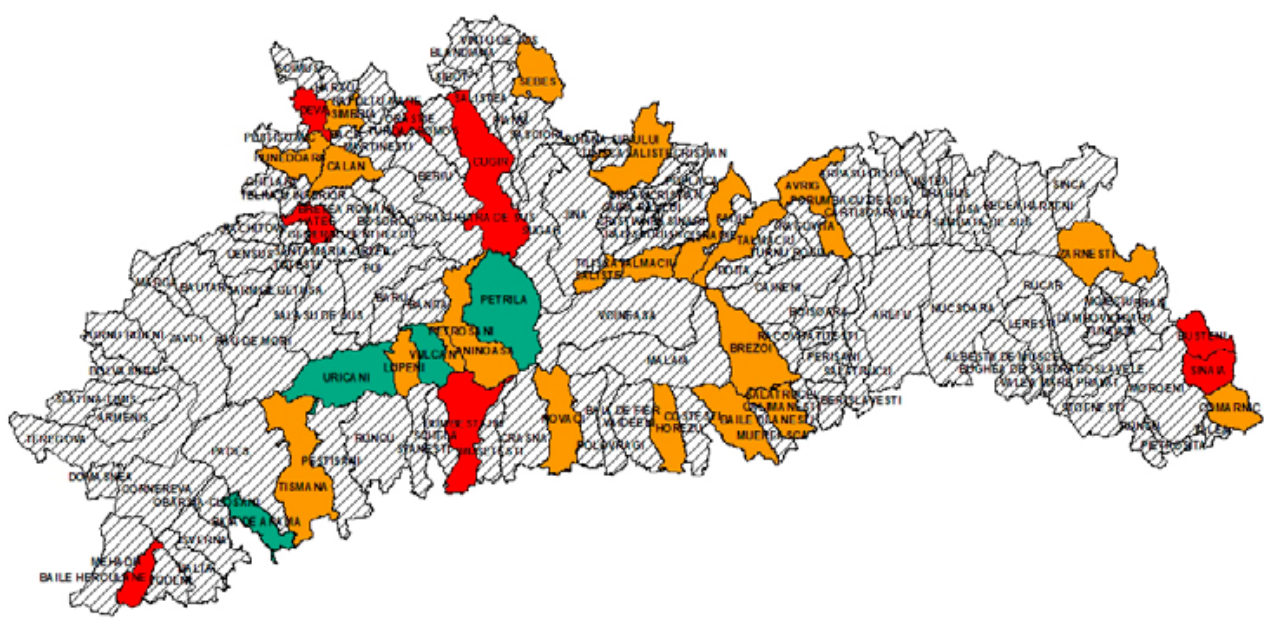

Legend:

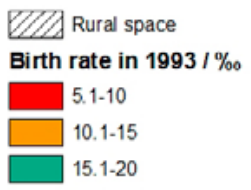

Figure 4.Geographic distribution of birth rates in urban area of the Southern Carpathians in 1993

Source: own study based on data from National Institute of Statistics 
dominates the three cities, which was seen in the evolution of birth. The large number of jobs and well remunerated in mining have positively influenced the birth. The highest rate of $18 \%$ was in the city of Baia de Aramă.

After 24 years, the birth rates in the urban area of the Southern Carpathians were in great decline. Rates recorded in 2017 appear in Figure 5. The highest rate was 10.1\%o in the town of Tălmaciu. In the 24 years, the birth rate decreased so much that in 2017,30 of the cities had their birth rates below $10.1 \%$. Moreover, in two administrative units the rate fell below 5.1\%o. Thus the lowest two rates were in: Sinaia of 3.9\%o and Băile Herculane 3.2\%. The rates of the three cities that had maximum rates in 1993, arrived after 24 years to fall almost by half or even more. The biggest drop was in Uricani, where the rate was $17.8 \%$ in 1993, and in 2017 it reached only 5.3\%o. This was the largest decrease recorded in 1993-2017 for the entire urban area of the Southern Carpathians. The second great decrease was in the Vulcan, where in 2017 the rate was 8\%o, decreasing from $15.6 \%$. In the Petrila, the rate recorded in 2017 was $8.1 \%$, compared with $15.2 \%$ as it was in 1993. The massive decreases in birth rates were mostly due to the loss of industrial function. Layoffs in the mining industry severely affected the birth of the three administrative units. The dysfunctions in the mining industry have begun to be visible since the 2002, when many of me were closed down to stop the activities.

The National Institute of Statistics provided in 2002 data far below those of 1992, on numerical herds in the mining and processing industries. At the Vulcan, the mining branch worked in 2002, 4744 people, with a deficit against 1992 of 2872 people. The population that active in the extraction decreased in the 10 years by $37.7 \%$. In the processing branch active in 2002, 1102 workers, decreasing with 1530. The reduction of workers in the Vulcan processing industry was a drastic $58.1 \%$. The population of the mining branch of the town of Petrila was in 2002, 3997 workers, decreasing with 2841. The decrease of the number of jobs in this branch was $41.5 \%$. From the manufacturing branch, the Petrila lost 729 workers, reaching 984, from 1713. The reduction of the herd of workers in the processing branch was $42.5 \%$. The town of Uricani was massively disindustrialised, so the number of those who activated in extraction fell by 1907 people, which means 54\%. The mining and quarrying industry of Uricani was most affected by industrial restructurings, registering the biggest losses of the workforce. The manufacturing mining industry lost 47.8\% of the labor mass, from 320 in 1992, to only 167 in 2002. Mining has put a lot of footprint on the birth of these industrial cities, with the demographic development closely linked to the mining function. As the function prospered, the evolution of birth was ascending, and when dysfunctions occurred in the mining industry, they transferred to the dynamic component.

The mortality of the 31 cities of the Southern Carpathians registered in the year 1993, a total of 5954 deaths. The dynamics of deaths in the period 1993-2017 to 31 administrative units are presented in Figure 6. The first three cities in descending order of the number of deaths are: Deva (684), Hunedoara (673) and Petroșani (510). The three had 1867 deaths together, 31.3\% of the total. Ten administrative units registered in 1993 under 100 deaths, being the lowest values in the urban area of the Southern Carpathians. The number of deaths recorded at the level of the ten cities was 1412 (23.7\% of the total), being divided as follows: Călimănești (99), Bumbești-Jiu (95), Uricani (80), Hore- 


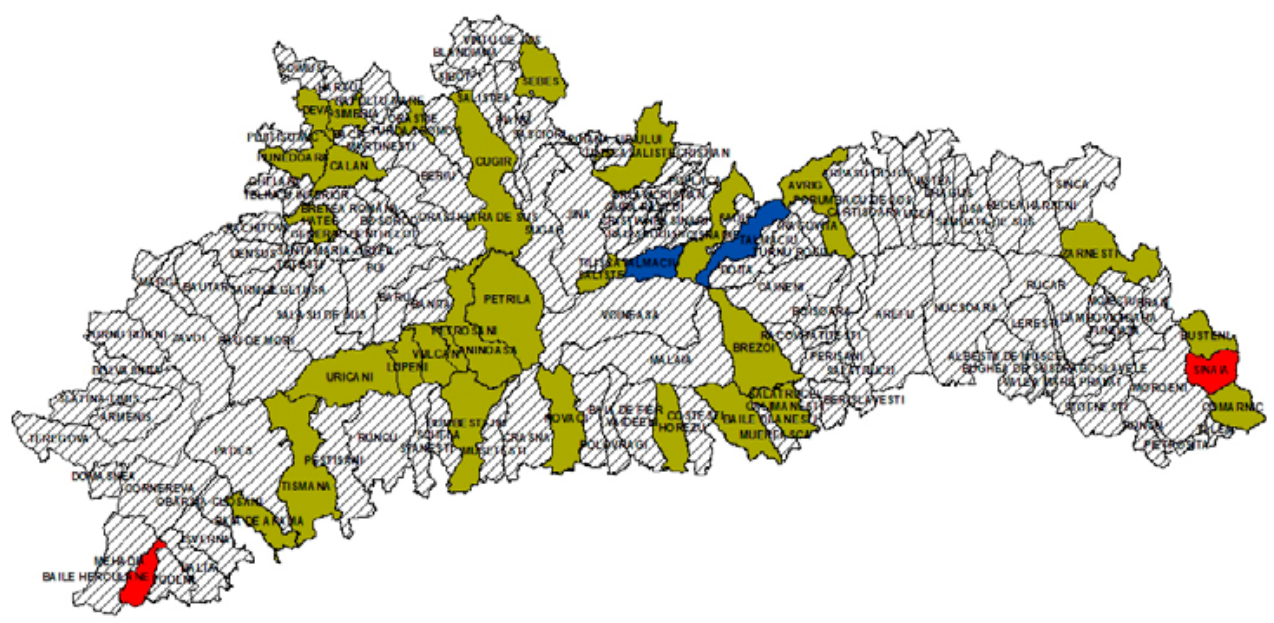

Legend:

שTA Rural space

Birth rate in $2017 / \%$ o

$1-5$

$\square$ 5.1-10

10.1-15

Figure 5. Geographic distribution of birth rates in urban area of the Southern Carpathians in 2017

Source: own study based on data from National Institute of Statistics

zu (77), Aninoasa (71), Brezoi (66), Novaci (63), Baia de Aramă (59), Băile Olănești (53), Băile Herculane (43).

In 2017, the situation was changed, with increasing numerical values of deaths. The number of deceased increased compared to 1993, with 316 people, registering a percentage increase of 5.3\%. The first three cities are maintained as in 1993, but with higher output values in the system. In Hunedoara, 859 deaths were recorded, with 186 more as in 1993. The increase was $27.6 \%$ in the 24 years. In Deva, the number of deaths increased compared to 1993 , with 142 reaching 2017 to 826 . This increase of 142 deaths means a percentage increase of $20.7 \%$. The city of Petroşani had a somewhat better situation of death, the number being lower than the values of the other cities. Thus, the difference between the number of deceased in 1993 and 2017 was only 17 people. The percentage increase was reduced in the 24 years of just $3.3 \%$. It is worth noting that the number of administrative units that had under 100 deceased persons increased from 10 to 11. Two cities fell below 100 deaths in 2017. Tălmaciu recorded in 1993, a number of 109 deaths, and in 2017 they reached 83. Sălişte fell from 101 in 1993, to 76 in 2017. Instead, the town of Bumbești-Jiu grew to more than 100 deaths, being the only one to pass 100 deceased persons between the ten in 1993 . Also, the number of people deceased decreased significantly from 1412 in 1993, to 737 in 2017. It is a numerical decrease of 675 deaths and a percentage decrease of $47.8 \%$. Practi- 


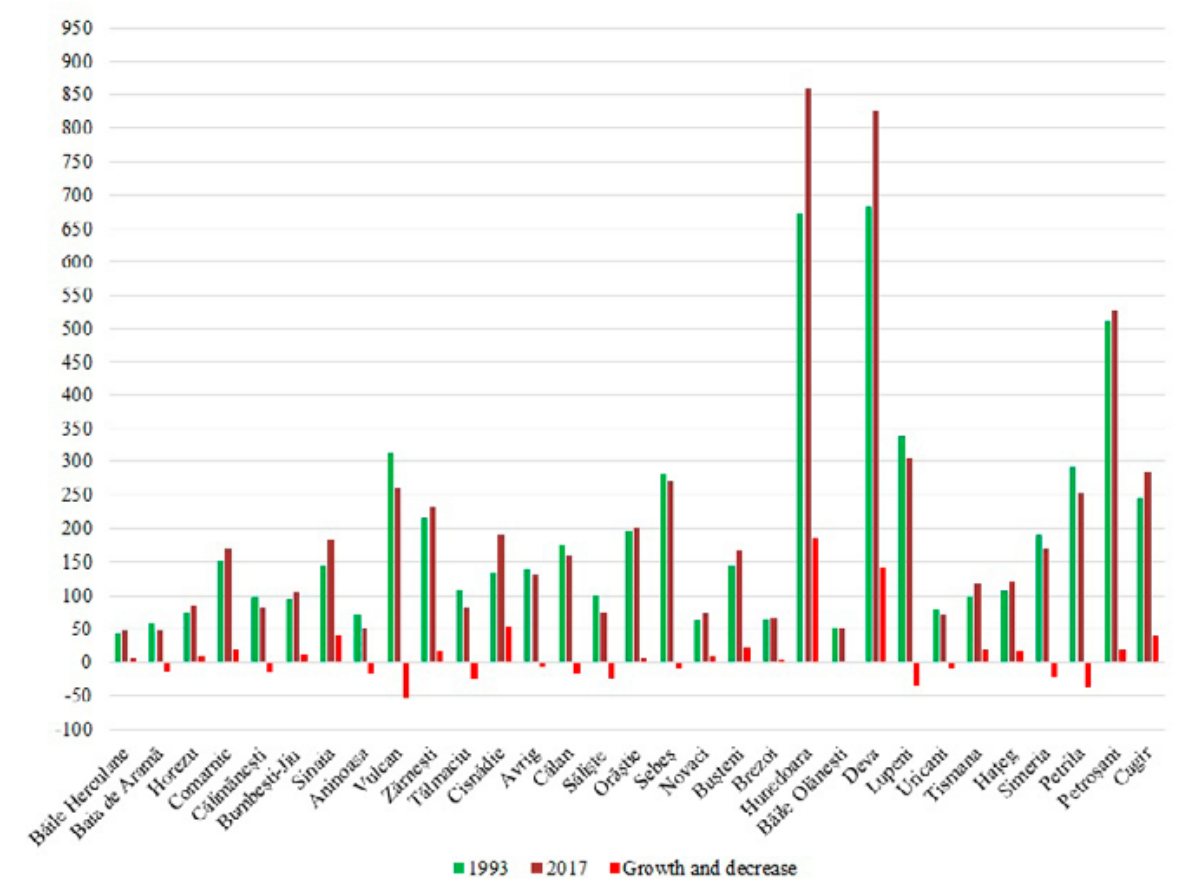

Figure 6. The numerical evolution of deaths in urban area of the Southern Carpathians in1993 and 2017

Source: own study based on data from National Institute of Statistics

cally, in some administrative units, deaths have declined in the same period, and in others have increased. In four cities, the population of the deceased has increased compared to 1993, but did not pass 100: Băile Herculane (43), Brezoi (67), Novaci (73), Horezu (86). Unfortunately, even though in some administrative units the number of deaths declined, they could not supplement the losses recorded by other cities. In 17 cities the number of deaths increased between 1993-2017. The difference between the year 1993 and 2017 can be seen in the total number registered in the 31 cities. The value of 2017 is above the value of 1993, which induces a certain demographic risk situation.

The mortality rates of the year 1993 (Figure 7) were ordered on three classes. Thus the lowest values of rates were between $5.1-10 \%$, comprising 18 administrative units. Of the 18, the last three rates that had the minimum values were in the cities: Cisnădie (7.7\%o), Băile Herculane (7.1\%o), Uricani (6.8\%o). 12 administrative units had the rates between $10.1-15 \%$ and the maximum rate passed by $15.1 \%$, being recorded by the city of Sălişte $(16.4 \%$ ). From these rates we can say that the urban space of the Southern Carpathians is not under the influence of high mortality rates. More than half of the cities had the death rates between 5.1-20\%, indicating that the population had small numerical values in terms of mortality. There is no risk of depopulation of cities due to high mortality in 1993. Unfortunately, the mortality rates were going to undergo big changes by 2017 , when the situation was presented completely differently. 


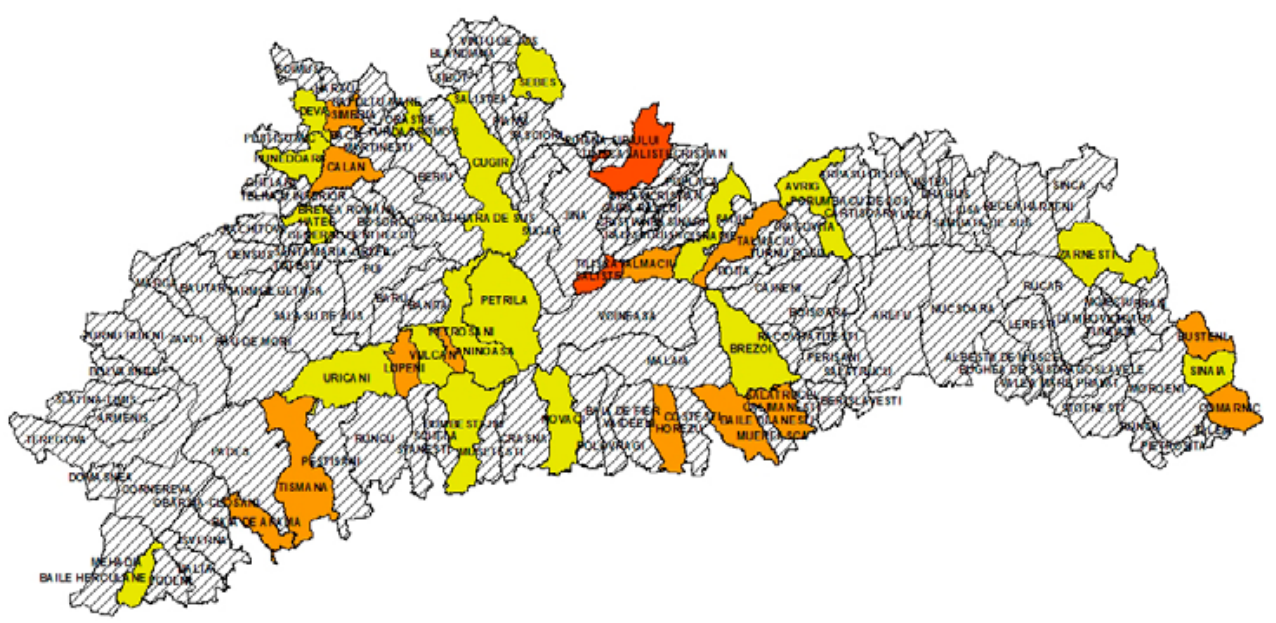

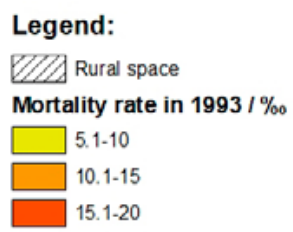

Figure 7. Geographical distribution of mortality rates in urban area of the Southern Carpathians in 1993

Source: own study based on data from National Institute of Statistics

As for 1993 and 2017 mortality rates (Figure 8) were ordered on three classes in order to be able to observe comparatively the evolution of the rates in the studied time period. If in 1993, the number of cities with rates between $5.1-10 \%$ amounted to 18 , after 24 years their number fell to 11. And these minimum rates have higher values than in 1993. Even if they are below $10 \%$, they have been continuously increasing with the possibility that in the next 10-20 years they will pass over $10 \%$. To demonstrate the increase in rates we mention the same as for 1993 the last three instalments: Zărnești (8.8\%), Sebeș and Baia de Aramă $(8.3 \%)$, Uricani $(7.4 \%$ ). The number of cities that had the rates between $10.1-15 \%$ o in 1993, increased from 12 to 17. It is the passage of cities that in 1993 were under 10\%o, at over $10.1 \%$ in 2017. Is the case of administrative units: Bumbești-Jiu, Hunedoara, Deva, Hațeg, Petrila, Cugir and Petroșani. There are also two cases where the rates fell to less than $10 \%$ compared to 1993 when they had the rate above $10.1 \%$. Those cities are: Baia de Aramă $(8.3 \%$ ) and Călimănești $(9.4 \%$ ). The exacerbation of mortality in the urban area is also visible by increasing the number of cities that had the rate in 2017, greater than $15.1 \% .24$ years ago, there was only one rate, and in 2017 , their number grew to three. The highest rate was in the city of Bușteni (17.2\%o), followed by Tismana (16.6\%) and Sinaia $(16.2 \%)$. Sinaia lost by mortality the most population during this period of time, reaching from a rate of $9.9 \%$ in 1993, at a rate of $16.2 \%$ in 2017. 


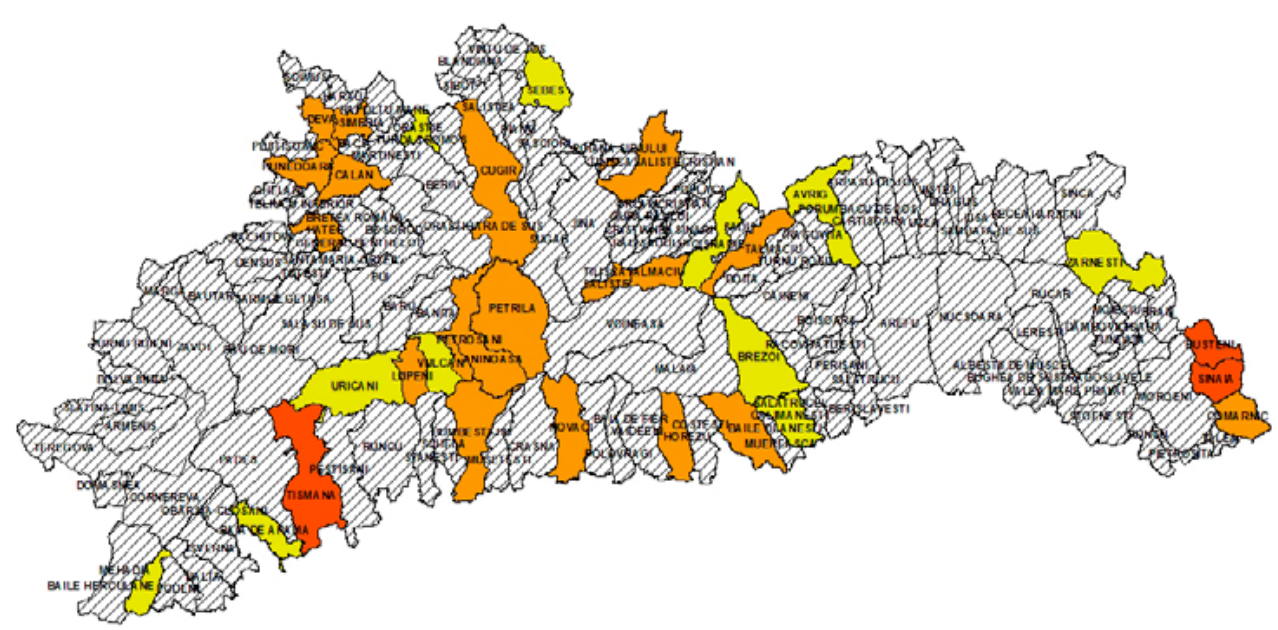

Legend:

एZ/ Rural space

Mortality rate in $2017 / \%$

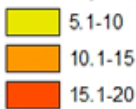

Figure 8. Geographical distribution of mortality rates in urban area of the Southern Carpathians in 2017

Source: own study based on data from National Institute of Statistics

In Figure 9 are represented the rates of natural growth in the period 1993-2017. Of the 31 cities, in only 2, positive rates of natural growth were recorded in the period studied. The positive rates were recorded in the cities of Tălmaciu (1.3\%o) and Săliște (1.7\%o). 29 administrative units have experienced large demographic dysfunction, the number of exits in the system (deaths), being superior to system inputs (births). Basically, in these 29 carpathian administrative units more people died than were born, inducing a risk of depopulation. It is confirmed that the natural dynamic of the population brings negative influences on the evolution of the values of demographic indicators. Uricani and Tismana had the highest negative rates, passing by $10.1 \%$. Instead, the values between $0-(-5) \%$ and $(-5.1)-(-10) \% 0$ almost equally comprised the urban area of the Southern Carpathians. From the geographic distribution of natural spore rates we can say that the cities of the Southern Carpathians face the depopulation phenomenon, for which the best ideas are to be sought, found and implemented to curb this demographic risk phenomenon. 


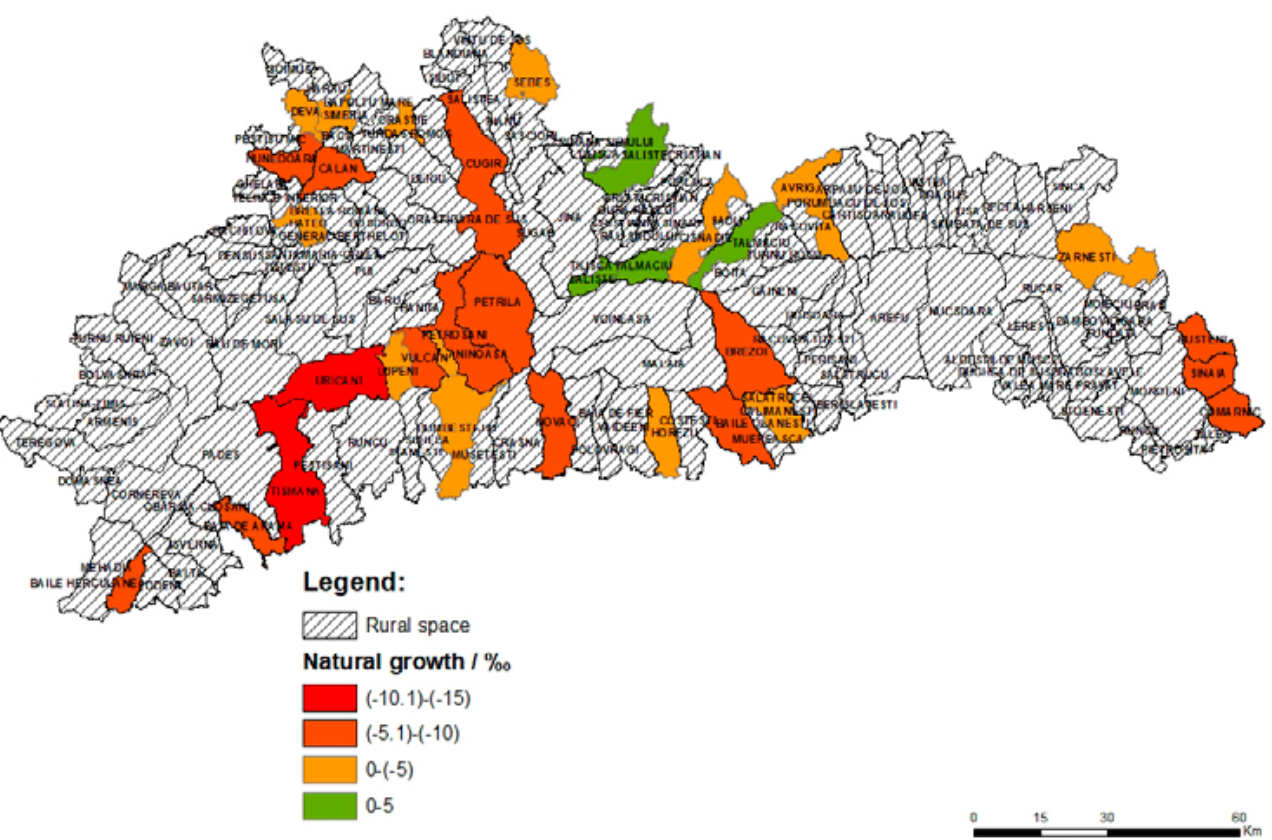

Figure 9. Geographical distribution of natural growthrates in urban area of the Southern Carpathians in 1993 and 2017

Source: own study based on data from National Institute of Statistics

\section{CONCLUSIONS}

The demographic evolution in the urban area of the Southern Carpathians has been steadily decreasing in the time analyzed. It is closely linked to the demographic changes, through birth, mortality and natural growth. The number of newborns was categorically lower than the number of deaths. Also, mortality rates were higher than birth rates, in this way, the natural growth by registering negative values. Of the 31 cities, only two had a positive natural growth so we can say that in the urban area of the Southern Carpathians, a demographic risk phenomenon is being exerted as depopulation. This demographic phenomenon has continuity due to the demographic changes, through greater actual outputs of the system (deaths) than the flocks of the system inputs (births), basically, the number of deaths is higher than the number of newborns.

Another cause that influenced the population changes in several cities was socio-economic. Much affected were the administrative units of the Petroşani Coal basin, where the industrial function has been dominating since the communist period. Basically, the labour force of cities was concentrated in the mining and processing industries of coal. 
With the end of the twentieth century and the beginning of the 21st century, industrial function diminished due to industrial restructurings occurring during the communist period. The capitalist period started with the year 1990 was very much passed on to the mining industry in these cities. In practice, the closures of the mines took place, and after the closures took place massive redundancies among the labor mass. The loss of jobs and the insecurity of income insurance have been passed on to the evolution and natural dynamics of the population of these mining towns.

\section{REFERENCES}

Attané, I.,\& Barbieri, M. (2009). The Demography of East and Southeast Asia from the 1950s to the 2000s. Population, 64(1): 9-146. DOI : 10.3917/popu.901.0007

Babović, S., Obradović, S-L., \&Prigunova I. (2016).Depopulation of villages in Southeastern Serbia as hindrance to economic development. J. Geogr. Inst. Cvijic, 66(1): 6174. DOI: 10.2298/IJGI1601061B

Constantin, V. (2011). Aşezările din arealele miniere din Munţii Apuseni: studiu de geografie aplicată [The settlements in the mining areas in the Apuseni Mountains: applied geography study]. Doctoral dissertation."Babeş-Bolyai” University of ClujNapoca. Faculty of Geography.

Fonogea, S., Gligor, V., \& Puiu, V. (2012). Dinamica populaţiei din bazinul hidrografic al Bistriței Ardelene în intervalul 1850-2010[Population dynamics in the river basin of Bistrița Transylvanian in the range 1850-2010], Geographia Napocensis, Year VI, nr.1, Cluj-Napoca, pp.89-100.

Ionescu, N-D. (2009). Populaţia şi aşezările din Dealurile Someşului Mare [Population and settlements in the hills of Someșului Mare].Doctoral dissertation. "BabeşBolyai" University of Cluj-Napoca. Faculty of Geography.

Jani, K. (2018). Demographic characteristics of creative workers: under-activated development potentials in Slovenia? Acta Geographica Slovenica, 58(2): 111-121.

Josipovic, D., \& Repolusk, P. (2003). Demographic Characteristics of the Romany in Prekmurje. Acta Geographica Slovenica, 43(1): 127-147.

Kokotović,V-K., Filipović, M., \& Panić M. (2016). Demographic characteristics of Lika Region. J. Geogr. Inst. Cvijic, 66(1) :45-59. DOI: 10.2298/IJGI1601045K

Lung, M-S. (2018). The natural dynamics of the rural population in Apuseni Mountains (2011 Census). Romanian Review on Political Geography/Revista Română de Geografie Politică, 20(2): 41-48, Oradea.

Lung, M-S., \&Gligor, V., (2018). Demographic changes in the urban space of Apuseni Mountains. Analele Universității din Oradea, Seria Geografie, 28(2): 164-173.

Marinković, I., \&Radivojević, B. (2016). Mortality trends and depopulation in Serbia. Geographica Pannonica, Volume 20, Issue 4, 220-226.DOI: 10.18421/GP20.04-04

Mihalca, A-I. (2010). Dinamica populației Microregiunii Târgu Lăpuș în perioada 19902009 [Population dynamics of the region Târgu Lăpuş from 1990-2009]. Geographia Napocensis, Year IV, nr.1, Cluj-Napoca, pp.89-100. 
Misachevici, A. (2011). Populaţia şi aşezările din Depresiunea Sibiului [Population and settlements of the Sibiu Depression].Doctoral dissertation. "Babeş-Bolyai" University of Cluj-Napoca. Faculty of Geography.

Niţă, A-F. (2007). Populaţia şi aşezările din Depresiunea Braşov [Population and settlements in the Brașov Depression].Doctoral dissertation. "Babeş-Bolyai" University of Cluj-Napoca. Faculty of Geography.

Persu, M-R. (2017). Demographic changes in the rural area of the Southern Carpathians (1992-2011). Rev. Roum. Géogr./Rom. Journ. Geogr., 61, (2), București, pp. 139-149.

Prioux, F., \&Mazuy, M. (2009), Recent Demographic Developments in France: Tenth Anniversary of the PACS Civil Partnership, and Over a Million Contracting Parties, Population, 64, 3, 393-442.

Posea, G., \&Badea, L. (1984). România. Unitățile de relief (Regionarea geomorfologică) [Romania. Relief units (Geomorphologic Regionals)]. Editura Științifică și Enciclopedică, București.

Raţiu, R-F. (2007). Populaţia şi aşezările din Câmpia Someşană (Câmpia Transilvaniei) [Population and settlements in Someşan Plain (Plain of Transylvania)]. Doctoral dissertation. "Babeş-Bolyai" University of Cluj-Napoca. Faculty of Geography.

Surd, V., Constantin, V., ... \& Nicula, A. S. (2017). Aş̧ezările din Munţii Apuseni [The settlements in the Apuseni Mountains]. Editura Presa Universitară Clujeană, ClujNapoca.

Tănasă, E. (2007). Populaţia şi aşezările din Câmpia Mureşană (Câmpia Transilvaniei) [Population and settlements in the Mureş Plain (Transylvania Plain)].Doctoral dissertation. "Babeş-Bolyai" University of Cluj-Napoca. Faculty of Geography.

Tofan, G-B. (2012). Drăgoiasa-Tulgheș depressionary alingment. The numerical evolution of population between 1850 and 2010. Studia Geographia, nr.1, Cluj-Napoca, pp.107-118.

Vîlcea, I-C. (2011). The characteristics of the evolution regarding the population growth in The Land Of Severin. Geographia Napocensis, Year V, nr.1, Cluj-Napoca, pp.49-58. National Institute of Statistics, Available at: http://statistici.insse.ro/shop/(20.11.2018). 